\title{
SOSIALISASI TEMPE SEBAGAI SUMBER PROTEIN BAGI IBU HAMIL DAN IBU MENYUSUI
}

\author{
Riris Lindiawati Puspitasari $^{{ }^{*}}$, Dewi Elfidasari ${ }^{1}$, Analekta Tiara Perdana1 \\ ${ }^{I}$ Program Studi Biologi, Fakultas Sains dan Teknologi, Universitas Al Azhar Indonesia \\ J1. Sisingamangaraja, Kompleks Masjid Agung Al Azhar, Kebayoran Baru Jakarta Selatan 12110 \\ Email Penulis Korespondensi: riris.lindiawati@uai.ac.id
}

\begin{abstract}
Abstrak
Angka Kematian Ibu (AKI) di Indonesia adalah yang tertinggi di kawasan ASEAN. Salah satu upaya yang dapat dilakukan untuk menurunkan AKI di Indonesia adalah dengan memberikan edukasi dan informasi tentang gizi bagi ibu terutama ibu hamil. Kandungan protein pada tempe dapat dimanfaatkan untuk pemenuhan kebutuhan protein ibu hamil dan menyusui. Masih terbatasnya informasi mengenai tempe sebagai sumber protein potensial bagi ibu hamil dan menyusui menyebabkan perlu dilakukan sosialisasi. Kegiatan pengabdian masyarakat dilakukan dengan tujuan untuk meningkatkan pengetahuan ibu hamil dan menyusui mengenai manfaat mengkonsumsi tempe sebagai asupan gizi sehari-hari. Sasaran kegiatan adalah kelompok ibu hamil dan menyusui di wilayah kerja praktek Bidan di Kotabumi Tangerang. Metode pelaksanaan kegiatan yaitu memberikan informasi mengenai manfaat tempe, mengadakan tanya jawab, dan memberikan pendampingan gizi terutama bagi ibu hamil dan menyusui disertai informasi terkini yang bersumber dari artikel jurnal terkait. Hasil pendataan awal menunjukkan bahwa pengetahuan yang dimiliki oleh ibu hamil dan menyusui belum sepenuhnya memahami potensi tempe. Sebagai tindak lanjutnya adalah melaksanakan sosialisasi potensi tempe dan hasil yang didapat menunjukkan bahwa sebagian besar peserta memberikan respon positif serta menyatakan perlunya menambahkan tempe sebagai menu harian keluarga.
\end{abstract}

Kata kunci: Ibu hamil, Ibu menyusui, Nutrisi, Sosialisasi, Tempe

\begin{abstract}
The Maternal Mortality Rate (MMR) in Indonesia is the highest in the ASEAN region. One effort that could be done to reduce MMR in Indonesia was by providing education and information on good nutrition. High protein content in tempe would be used to meet the body's protein needs such as body tissue formation, especially in pregnant and lactating women. The limited information about tempe as a potential protein source for pregnant and lactating women caused the need to conduct socialization, especially in Tangerang, the activity carried out by socializing the benefits of tempe as a source of protein. The target activities were pregnant and lactating women in Kotabumi, Tangerang as widwifery practice work area. The results of the initial data collection indicated that the knowledge possessed by pregnant and lactating mothers did not fully understand about the potential of tempe. After socialization, it was seen that mothers' understanding could increase based on discussion session.
\end{abstract}

Keywords: Lactating women, Nutrition, Pregnant women, Socialization, Tempe

\section{PENDAhuluaN}

Salah satu upaya yang dapat dilakukan untuk menurunkan Angka Kematian Ibu di Indonesia adalah dengan memberikan edukasi dan informasi tentang gizi yang baik dan diperlukan saat masa kehamilan, persalinan dan masa nifas (Helmizar, 2014; Wulandari \& Utomo, 2017). Makanan ibu hamil dan menyusui hendaknya mengandung jumlah dan mutu gizi optimal 
mendukung perkembangan janin, menghasilkan ASI yang baik dan sekaligus dapat mempercepat proses penyembuhan luka pasca melahirkan. Makanan yang mengandung zat pertumbuhan ataupun pembangun seperti protein merupakan makanan yang diperlukan untuk pertumbuhan janin dan plasenta, pertumbuhan kelenjar susu dan meningkatkan metabolisme tubuh (Karima \& Achadi, 2012).

Tempe merupakan sumber protein khas Indonesia yang dibuat menggunakan kultur campuran Rhizopus spp., terutama Rhizopus oligosporus, Rhizopus oryzae, $R$. arhizus, $R$. stolonifer dan R. Microspores (Harahap, Lubis, $\&$ Kaban, 2018). Tempe memiliki rasa dan tekstur yang menarik, daya cerna yang sangat tinggi, serta beberapa efek positif terhadap kesehatan seperti mengurangi resiko penyakit jantung, stroke, osteoporosis, kanker, kelainan pencernaan, serta gejala-gejala menopause (Koeryaman \& Ermiati, 2018). Selain itu, tempe juga kaya akan nutrisi dan substansi aktif seperti protein dan nitrogen terlarut, asam amino dan asam lemak bebas, isoflavon, serta vitamin $\mathrm{B}_{12}$ (Harahap, Lubis, \& Kaban, 2018).

Tempe juga mengandung beragam vitamin dan zat besi $(\mathrm{Fe})$ yang dapat dimanfaatkan untuk sintesis sel $\mathrm{Hb}$ darah, terutama bagi ibu hamil dan menyusui (Sumiyarsi, Nugraheni, Mulyani, $\&$ Budi, 2018). Pengetahuan ibu tentang gizi sangat berkaitan dengan pemenuhan kebutuhan nutrisinya saat hamil. Tingkat pengetahuan ibu dipengaruhi oleh pengalaman, faktor pendidikan, lingkungan, sosial, sarana dan prasarana maupun derajat penyuluhan yang diperoleh. Ibu hamil dengan pengetahuan gizi yang baik diharapkan dapat memilih makanan yang bergizi baik (Anggraini, 2018). Masih terbatasnya informasi mengenai tempe sebagai sumber protein potensial bagi ibu hamil dan menyusui dan belum adanya upaya untuk melakukan sosialisasi di kota Tangerang, menyebabkan perlu dilakukan kegiatan sosialisasi ini bagi ibu hamil dan menyusui di kota Tangerang, serta kerabat terdekat ibu, bidan desa dan masyarakat terutama yang berjenis kelamin wanita.

Kegiatan ini bertujuan untuk melakukan sosialisasi kepada ibu hamil dan menyusui di kota Tangerang, serta kerabat terdekat ibu, bidan, dan masyarakat terutama yang berjenis kelamin wanita mengenai tempe sebagai sumber protein potensial bagi ibu hamil dan menyusui.
Manfaat dari kegiatan adalah memberikan informasi dan pemahaman kepada ibu hamil dan menyusui di kota Tangerang bahwa tempe adalah sumber protein potensial bagi ibu hamil dan menyusui. Selain itu juga kepada kerabat terdekat ibu, bidan, dan masyarakat untuk terlibat aktif mendukung upaya ibu dalam memenuhi kebutuhan gizinya

\section{METODE PELAKSANAAN}

Kegiatan ini dilakukan pada bulan Januari hingga September 2018 di kota Tangerang. Kegiatan dilakukan di praktik Bidan Siti Fatimah, AMKeb. di wilayah Kota Bumi, Tangerang dengan peserta ibu hamil dan menyusui yang tercatat sebagai pasien di praktik bidan tersebut. Jenis kegiatan terdiri dari penyuluhan disertai pemeriksaan kesehatan dan status gizi. Peralatan yang digunakan antara lain timbangan berat badan, pengukur tinggi badan, stateskop, tensi meter, dan perlengkapan untuk ceramah.

Penyuluhan gizi tidak hanya diberikan kepada ibu hamil dan menyusui tetapi juga kepada kerabat terdekat ibu, bidan desa dan masyarakat terutama yang berjenis kelamin wanita. Penyuluhan gizi difokuskan mengenai tempe sebagai sumber protein potensial bagi ibu hamil dan menyusui. Selain itu juga diberikan informasi mengenai makanan sehat berupa 4 sehat 5 sempurna untuk ibu hamil dan menyusui. Peserta penyuluhan diberi wawasan tentang tempe sebagai sumber protein potensial bagi ibu hamil dan menyusui, serta informasi mengenai makanan sehat berupa 4 sehat 5 sempurna untuk ibu hamil dan menyusui.

Pemeriksaan kesehatan dan status gizi ibu hamil dan menyusui dilakukan setelah penyuluhan. Kegiatan ini dilakukan agar ibu hamil dan menyusui dapat memantau dan menjaga kondisi kesehatan tubuhnya, mengetahui status gizinya sehingga dapat memperbaiki pola makan menjadi lebih baik. Pemeriksaan kesehatan yang umum dilakukan bagi ibu hamil dan menyusui diantaranya pengukuran tekanan darah, tinggi badan dan berat badan. 


\section{HASIL DAN PEMBAHASAN}

Karakteristik ibu dapat dilihat pada Tabel 1. Karakteristik ibu yang diamati antara lain usia, pendidikan, pekerjaan, usia kehamilan, dan kehamilan ke berapa.

Tabel 1. Karakteristik ibu hamil dan ibu menyusui

\begin{tabular}{|c|c|c|c|c|}
\hline No & \multicolumn{2}{|c|}{ Karakteristik Ibu } & Jumlah & $(\%)$ \\
\hline \multirow[t]{4}{*}{1} & \multirow{4}{*}{$\begin{array}{l}\text { Usia } \\
\text { (tahun) }\end{array}$} & $21-25$ & 7 & 46,67 \\
\hline & & $26-30$ & 4 & 26,67 \\
\hline & & $31-35$ & 2 & 13,33 \\
\hline & & $36-40$ & 2 & 13,33 \\
\hline \multirow[t]{3}{*}{2} & \multirow{3}{*}{$\begin{array}{l}\text { Pendidikan } \\
\text { SMA atau } \\
\text { sederajat }\end{array}$} & Dasar: SD & 3 & 20 \\
\hline & & $\begin{array}{l}\text { Menengah: } \\
\text { SMP- } \\
\text { SMA; } \\
\text { sederajat }\end{array}$ & 9 & 60 \\
\hline & & $\begin{array}{l}\text { Tinggi: } \\
\text { diploma- } \\
\text { S1 }\end{array}$ & 3 & 13,33 \\
\hline \multirow[t]{3}{*}{3} & \multirow[t]{3}{*}{ Pekerjaan } & $\begin{array}{l}\text { Ibu rumah } \\
\text { tangga }\end{array}$ & 7 & 46,67 \\
\hline & & Karyawan & 7 & 46,67 \\
\hline & & Guru & 1 & 6,67 \\
\hline \multirow[t]{3}{*}{4} & \multirow{8}{*}{$\begin{array}{l}\text { Usia } \\
\text { kehamilan } \\
\text { (minggu) } \\
\text { Kehamilan } \\
\text { anak }\end{array}$} & $1-12$ & 4 & 26,67 \\
\hline & & $13-24$ & 7 & 46,67 \\
\hline & & $25-36$ & 4 & 26,67 \\
\hline \multirow[t]{5}{*}{5} & & $\mathrm{Ke}-1$ & 7 & 46,67 \\
\hline & & $\mathrm{Ke}-2$ & 4 & 26,67 \\
\hline & & $\mathrm{Ke}-3$ & 1 & 6,67 \\
\hline & & $\mathrm{Ke}-4$ & 2 & 13,33 \\
\hline & & $\mathrm{Ke}-6$ & 1 & 6,67 \\
\hline
\end{tabular}

Tabel 1 memperlihatkan karakteristik ibu hamil dan ibu menyusui di wilayah pengabdian masyarakat. Persentase tertinggi diperoleh untuk setiap karakteristik adalah sebanyak $47 \%$ ibu berumur 21-25 tahun, $47 \%$ berpendidikan SMA/sederajat, $47 \%$ ibu rumah tangga (IRT) dan karyawan, $46 \%$ ibu dengan usia kehamilan 13-24 minggu, dan $38 \%$ ibu mengandung anak pertama.

Tingginya jumlah responden yang berusia $<$ 26 tahun menunjukkan bahwa di wilayah kerja bidan Siti Fatimah, pasien yang memeriksakan kandungannya maupun yang kontrol setelah melahirkan tergolong usia muda. Menurut penelitian (Mufti, 2018) kehamilan yang tidak diinginkan merupakan dampak dari kehamilan di usia muda. Pada usia sangat muda, psikologis seorang wanita masih belum mencapai kestabilan dalam mengendalikan emosi dan tekanan kehidupan.

\section{Penyuluhan Gizi Ibu Hamil dan Ibu Menyusui}

Pengetahuan ibu hamil dan ibu menyusui terhadap asupan gizi seimbang dan manfaatnya bagi kebutuhan nutrisi ibu hamil dan ibu menyusui diketahui berdasarkan pre test dan post test kegiatan penyuluhan. Penyuluhan gizi tidak hanya diberikan kepada ibu hamil dan menyusui tetapi juga kepada kerabat terdekat ibu, bidan, dan masyarakat terutama yang berjenis kelamin wanita. Penyuluhan gizi difokuskan mengenai tempe sebagai sumber protein potensial bagi ibu hamil dan menyusui. Selain itu juga diberikan informasi mengenai makanan sehat berupa 4 sehat 5 sempurna untuk ibu hamil dan menyusui. Penyuluhan diberikan kepada ibu hamil dan menyusui, khususnya yang berusia di bawah 30 tahun dan hamil atau baru melahirkan anak pertama. Penyuluhan gizi tidak hanya diberikan kepada ibu hamil dan menyusui tetapi juga kepada kerabat terdekat ibu, bidan, dan masyarakat terutama yang berjenis kelamin wanita. Berikut gambaran peningkatan wawasan responden mengenai manfaat tempe bagi janin dan bayi (Tabel 2).

Tabel 2. Hasil pre test dan post test responden

\begin{tabular}{clcc}
\hline \multirow{2}{*}{ No } & \multicolumn{1}{c}{ Pernyataan } & $\begin{array}{c}\text { Post test } \\
\text { Setuju } \\
(\%)\end{array}$ & $\begin{array}{c}\text { Pre test } \\
\text { Setuju } \\
(\%)\end{array}$ \\
\hline 1 & $\begin{array}{l}\text { Nasi, roti, dan mie } \\
\text { sebagai } \\
\text { karbohidrat }\end{array}$ & 76 & 60 \\
2 & $\begin{array}{l}\text { Ikan, telur, daging, } \\
\text { kacang sebagai sumber } \\
\text { protein }\end{array}$ & 80 & 62 \\
3 & $\begin{array}{l}\text { Sayur dan buah sebagai } \\
\text { sumber vitamin }\end{array}$ & 87 & 50 \\
4 & $\begin{array}{l}\text { Tempe sebagai makanan } \\
\text { padat gizi } \\
\text { Tempe dapat diolah } \\
\text { menjadi lauk }\end{array}$ & 83 & 20 \\
6 & $\begin{array}{l}\text { Tempe terbuat dari } \\
\text { kacang kedelai } \\
\text { Tempe dapat dijadikan } \\
\text { lauk sebagai pengganti } \\
\text { daging }\end{array}$ & 87 & 50 \\
\end{tabular}

Tabel 2 memperlihatkan bahwa terdapat peningkatan wawasan ibu hamil dan ibu menyusui tentang manfaat tempe sebagai nutrisi padat gizi. Setelah kegiatan penyuluhan, responden menjadi mengerti dan bersedia untuk memasukkan tempe sebagai menu harian keluarga. Responden berminat untuk 
memvariasikan pengolahan tempe agar tidak menimbulkan kebosanan. Kandungan gizi yang dimiliki tempe salah satunya dapat mencegah kejadian anemia bagi ibu hamil dan ibu menyusui (Anggraini, 2018).

Pengetahuan ibu peserta sosialisasi mengalami peningkatan dibanding sebelum dilakukan kegiatan. Peningkatan wawasan mengenai manfaat mengkonsumsi tempe sebagai asupan nutrisi penting saat hamil dan menyusui juga telah dilakukan peneliti lain (Yulianti \& Sari, 2018). Kebutuhan protein sangat penting bagi pertumbuhan dan perkembangan sel-sel janin sehingga diharapkan tidak terjadi malnutrisi yang akan berdampak malformasi dan abnormalitas pertumbuhan (Mutia, 2018). Adanya kejadian balita dengan kondisi stunting atau keadaan kurang gizi pada balita yang menahun telah memperjelas pentingnya asupan gizi seimbang pada ibu hamil dan menyusui (Risnah, Rosmah, Mustamin, \& Sofingi, 2018). Hal serupa juga ditemukan pada kegiatan pengabdian yang dilakukan oleh (Hardiyanti, Majid, \& Umar, 2018).

Pemeriksaan kesehatan dan status gizi ibu hamil dan menyusui dilakukan setelah penyuluhan. Kegiatan dilakukan agar ibu hamil dan menyusui dapat memantau dan menjaga kondisi kesehatan tubuhnya, mengetahui status gizinya sehingga dapat memperbaiki pola makan menjadi lebih baik. Pemeriksaan kesehatan yang umum dilakukan bagi ibu hamil dan menyusui diantaranya pengukuran tekanan darah, tinggi badan dan berat badan. Berikut dokumentasi kegiatan (Gambar 1, 2, dan 3).

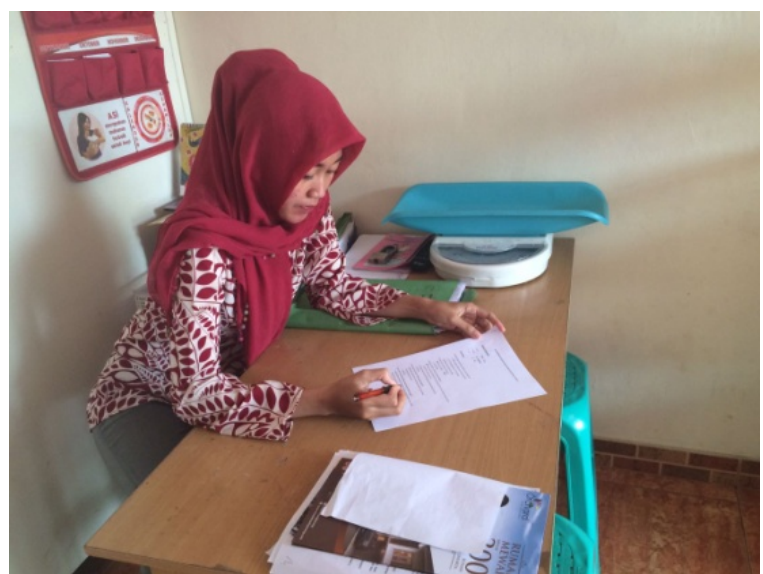

Gambar 1. Kegiatan pengisian kuesioner pemanfaatan tempe

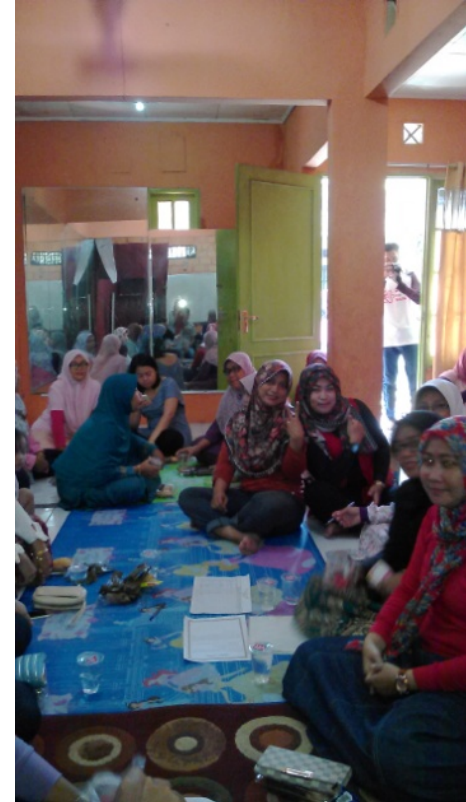

Gambar 2. Kegiatan sosialisasi ke-1 pemanfaatan tempe

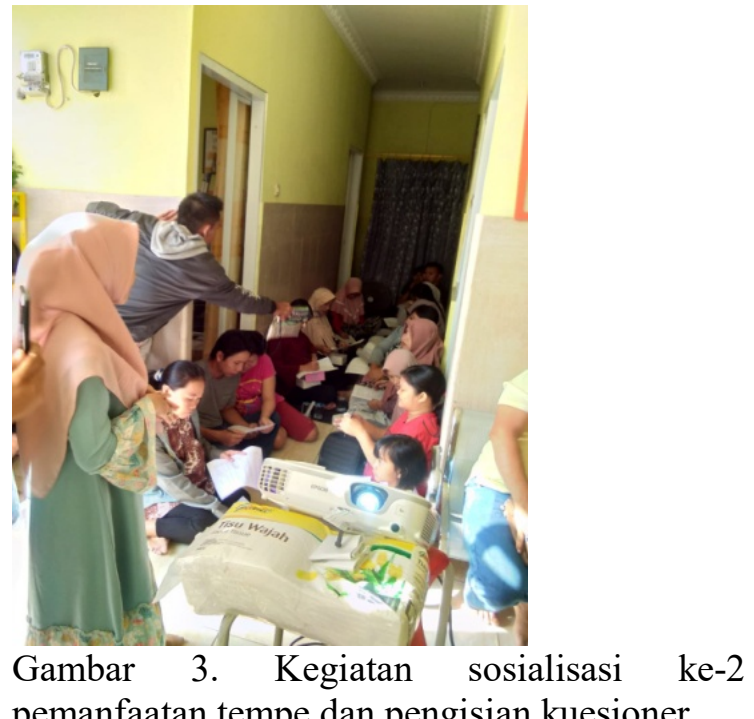

pemanfaatan tempe dan pengisian kuesioner

Kegiatan penyuluhan (Gambar 1, 2, dan 3) manfaat tempe bagi ibu hamil dan ibu menyusui yang dilakukan di saat kegiatan kontrol kesehatan berlangsung dengan lancar. Antusiasme para ibu ditunjukkan melalui aktifnya responden dalam menjawab maupun mengajukan pertanyaan kepada pemateri. Penyuluhan dilakukan agar ibu hamil dan menyusui dapat memantau dan menjaga kondisi kesehatan tubuhnya, mengetahui status gizinya sehingga dapat memperbaiki pola makan menjadi lebih baik. Pemeriksaan kesehatan yang umum dilakukan bagi ibu hamil dan menyusui diantaranya pengukuran tekanan darah, tinggi badan dan berat badan. 


\section{SIMPULAN DAN SARAN}

\section{Simpulan}

Berdasarkan kegiatan Sosiaolisasi Tempe Sebagai Sumber Protein Bagi Ibu hamil dan Ibu Menyusui diperoleh kesimpulan bahwa (1)Karakteristik ibu hamil dan ibu menyusui berusia muda (21-25 tahun) sebanyak 46,67\%, berpendidikan menengah $60 \%$, sebagai ibu rumah tangga ataupun karyawan $46 \%$, kehamilan anak pertama sebanyak $46 \%$, dan sedang mengandung 6 bulan sebanyak $46 \%$. (2) Transfer informasi yang dilakukan melalui penyuluhan dapat diterima dengan baik oleh responden. (3) Sebanyak lebih dari 70\% ibu telah memiliki wawasan mengenai kandungan gizi tempe bagi peningkatan kesehatan janin dan bayi.

\section{Saran}

Perlu dilakukan kegiatan monitoring peningkatan gizi ibu hamil dan menyusui di wilayah pelaksanaan abdimas.

\section{UCAPAN TERIMA KASIH}

Pelaksana pengabdian kepada masyarakat mengucapkan terima kasih kepada Lembaga Penelitian dan Pengabdian Kepada Masyarakat UAI atas dukungan pendanaan melalui Grant Pengabdian kepada Masyarakat Internal UAI 2018.

\section{DAFTAR PUSTAKA}

Anggraini, D. D. (2018). Faktor Predisposisi Ibu Hamil dan Pengaruhnya terhadap Kepatuhan Mengkonsumsi Tablet Besi (FE) dan Anemia pada Ibu Hamil. Strada Jurnal Ilmiah Kesehatan, 9-22.

Harahap, R. H., Lubis, Z., \& Kaban, J. (2018). Komponen Flavor Volatil Tempe yang Dibungkus dengan Daun Pisang dan Plastik. Agritech, 194-199.
Hardiyanti, N., Majid, M., \& Umar, F. (2018). Hubungan Pola Makan Ibu Menyusui Dengan Status Gizi Bayi Usia 0-6 Bulan Di Wilayah Kerja Puskesmas Suppa. Manusia dan Kesehatan, 242-254.

Helmizar. (2014). Evaluasi Kebijakan Jaminan Persalinan (JAMPERSAL) Dalam Penurunan Angka Kematian Ibu Dan Bayi Di Indonesia. KEMAS, 197-205.

Karima, K., \& Achadi, E. L. (2012). Status Gizi Ibu dan Berat Badan Lahir Bayi. Kesmas, 111-119.

Koeryaman, M. T., \& Ermiati. (2018). Adaptasi Gejala Perimenopause Dan Pemenuhan Kebutuhan SeksualL Wanita Usia 50-60 Tahun. MEDISAINS, 21-30.

Mutia, M. S. (2018). Faktor Resiko Kematian Perinatal Di RSUD Dr Pirngadi Medan. Penelitian Pendidikan MIPA, 208-216.

Risnah, Rosmah, Mustamin, \& Sofingi, I. (2018). Pengaruh Pelatihan Terhadap Pengetahuan Tentang Gizi Buruk Dan InterProfesional Collaboration Petugas Puskesmas. Kesehatan, 61-71.

Sumiyarsi, I., Nugraheni, A., Mulyani, S., \& Budi, E. (2018). Faktor-faktor Yang Mempengaruhi Hemoglobin Ibu Hamil Trimester III. PLACENTUM, 20-25.

Wulandari, D. A., \& Utomo, I. H. (2017). Responsivitas Dinas Kesehatan Kabupaten Karanganyar dalam Upaya Menurunkan Angka Kematian Ibu (AKI) dan Angka Kematian Bayi (AKB) di Kabupaten Karanganyar. Wacana Publik, 40-49.

Yulianti, S., \& Sari, N. N. (2018). Upaya Perbaikan Gizi Dengan Pemberian Makanan Tambahan Papa Ny.D Umur 24 Th G1 Kronis (KEK) Di BPM Satiarmi Kota Bengkulu Tahun 2018. Midwifery, 35-40. 